\title{
Ecotoxicity and Ecosystem Health of a Ramsar Wetland System of India
}

\author{
U. P. Nasir ${ }^{1 *}$, P. S. Harikumar ${ }^{2}$ \\ ${ }^{1}$ Senior Scientific Assistant, Central Pollution Control Board, Zonal Office-Vadodara, Gujarat, India; ${ }^{2}$ Scientist \& In-Charge, Central \\ Water Analysis Laboratory, Centre for Water Resources Development and Management, Kozhikode, Kerala, India. \\ Email: nasirchemistry@yahoo.com,drpshari@yahoo.co.in
}

Received March 22 ${ }^{\text {nd }}, 2011$; revised May $4^{\text {th }}, 2011$; accepted June $14^{\text {th }}, 2011$.

\begin{abstract}
In this study one economically important Ramsar wetland system of India, Vembanad wetland system, is studied to determine the environmental pollution. Six surface sediment samples collected from two extreme zones of the wetland system were analyzed for heavy metals such as Copper, Zinc, Manganese, Cadmium, Lead, Nickel and Mercury. Highest metal concentration was found at industrial zone and lowest concentration was detected at southern upstream of the wetland system. The results showed that the pollution level is significant in the industrial zone. Comparison of the results with different sediment quality guidelines indicated ultra high degree of contamination in the industrial zone. The numerical value of degree of contamination, pollution load index, sum of toxic units, enrichment factor and geo-accumulation index confirmed the above fact. Based on National Oceanic and Atmospheric Administration Guidelines, the health of the ecosystem was seriously impaired with frequent occurring of biological effects in the industrial zone. The percentage of heavy metal calculated with respect to the industrial zone as the base line and the correlation analysis with organic matter indicated that, mobility of the specific metal has higher impact on its concentration at the fresh water region of the wetland.
\end{abstract}

Keywords: Heavy Metal, Sediment Quality Guidelines, Degree of Contamination, Pollution Load Index, Index of Geo-Accumulation

\section{Introduction}

Sediments are the layers of relatively finely divided matter covering the bottom of rivers, streams, lakes, reservoirs, bays, estuaries and ocean. Unlike water quality which is susceptible to seasonal variation, dependent on in and out flow and weather, sediment quality is more constant and will have more farfetched implications. Assessment of sediments in a complex aquatic system resulted in a better understanding of the adverse impacts that contaminants in sediments pose to fish, wild life and humans who depend this impacted waterways. Therefore apart from polluted water, fate of contaminated sediment has been chosen as one of the aspects responsible for ecological decline. Lake sediments provide a useful archive of information on changing lacustrine and watershed ecology [1]. The composition of the sediment sequences provides the best natural achieves of recent environmental changes [2].

Sediment is a habitat and major nutrient source for aquatic organisms. Sediment analysis is important in eva- luating qualities of total ecosystems of a water body in addition to water sample analysis practiced for many years because it reflects the long term quality situations independent of the current inputs [3] and it is the ultimate sink of contaminants in the aquatic system [4]. Accumulation of heavy metals occur in upper sediment of the aquatic environment by biological and geochemical mechanisms and becomes toxic to sediment dwelling organisms and fish, resulting in death, reduced growth, or in impaired reproduction and lower species diversity [5]. Trace elements also occur naturally in rock forming minerals; hence they can reach the environment from natural processes [6]. The occurrence of metals in aquatic ecosystems in excess of natural background loads has become a problem of increasing concern. Heavy metals in environment may accumulate to toxic levels without visible signs. This may occur naturally from normal geological phenomenon such as ore formation, weathering of rocks and leaching or due to increased population, urbanization, industrial activities, agricultural practices, exploration and exploitation of natural resources [7]. 
One of the major problems that heavy metals cause with respect to their effects on aquatic organisms is their long biological half-life. Therefore, they are among the most frequently monitored micropollutants, and reliable techniques have been established for their extraction and quantification [8-10], since sediment contamination by heavy metals in rivers and estuaries has become an issue of increasing environmental concern. Such contamination is often caused by human activities, including mining, smelting, electroplating and other industrial processes that have metal residues in their wastes, and by non-point source surface runoff.

It is accepted that without defensible sediment quality guidelines it would be difficult to assess the extend of sediment contamination [11]. Sediments were classified as non-polluted, moderately polluted and heavily polluted, based on Sediment Quality Guidelines of United State Environmental Protection Agency [12]. Hakanson et al. [13] had suggested a contamination factor (Cif) and the degree of contamination $(\mathrm{Cd})$ to describe the contamination of given toxic substance. Tomlinson et al. [14] had employed a simple method based on pollution load index (PLI) to assess the extent of pollution by metals in estuarine sediments. The need for chemical guidelines that could be used to predict adverse biological effects in contaminated sediments lead to the development of sediment quality guidelines [15-18]. The ecotoxicological sense of heavy metal contamination in sediments was determined using sediment quality guidelines developed for marine and estuarine ecosystem [19]. The potential acute toxicity of contaminants in sediment sample can be estimated as the sum of the toxic units ( $\left.\sum \mathrm{TU}\right)$ defined as the ratio of the determined concentration to PEL value [20]. Pollution will be measured as enrichment factor (EF), which is the amount or ratio of the sample metal enrichment above the concentration present in the reference station or material $[21,22]$. Sediment geo accumulation index (Geol) is the quantitative check of metal pollution in aquatic sediments [23]. These impacts were assessed by means of the geo-accumulation index (Igeo) [24] and Igeo classification is reported based on the chemical analysis of the bulk sediments. The Igeo has been widely utilized as a measure of pollution in freshwater [25-27] and marine sediments [28-30].

The over all objective of this research work was to evaluate the degree and extend to which the heavy metal contamination has affected the Vembanad wetland system, one of the Ramsar site in the south west coast of India. In this study heavy metals such as copper, zinc, manganese, cadmium, lead, nickel and mercury in surface sediments were analysed using different sediment quality guidelines. The numerical value of different sediment quality indices such as degree of contamination, pollution load index, sum of toxic units, enrichment factor and geo-accumulation index were also calculated for the data interpretation. Hence the present study aimed to understand the pollution load at industrial region of the wetland system and its impact towards the fresh water region of the Vembanad Lake.

The Vembanad wetland system (Latitude $9^{\circ} 30^{\prime}$ and $10^{\circ} 12^{\prime}$; Longitude $76^{\circ} 10^{\prime}$ and $76^{\circ} 29^{\prime}$ ) is a complex aquatic system of coastal backwaters, lagoons, marshes, mangroves and reclaimed lands with an intricate network of natural and man made channels and its associated drainage basins are situated in the humid tropical region on the south west coast of the Indian peninsula. The total area of the wetland system is $2195 \mathrm{~km}^{2}$. This system includes the Vembanad backwaters and the lower reaches of the five rivers draining in to it. The five rivers which drain in to the Vembanad Lake are Muvattupuzha, Meenachil, Manimala, Pamba and Achenkoil. All these rivers originate from the Western Ghats, flow westwards through the wetland system and join the Lakshadweep/ Arabian Sea. The wetland is typically divided into two distinct segments, the freshwater dominant southern zone and the salt-water dominant northern zone both separated by a bund at Thanneermukkom. The estuarine zone and organically rich sedimentary substratum of the inshore region makes it a highly preferred and desirable habitat for shrimps breeding. Vembanad is renowned for its live clam resources and sub-fossil deposits. Vembanad wetland has been designated as a Ramsar Site in November 2002.

The wetland system is facing many problems, which include; pollution due to industrial, agricultural and domestic effluents. It is estimated that nearly 260 million liters of effluents reach the estuaries daily form the industries located in the northern part of the wetland system [31]. The Cochin estuarine system receives effluents containing a large dose of heavy metals [32]. The distribution and toxicity of heavy metals in core sediments also indicated severe pollution in the wetlands [33,34]. The increasing loads of sewage and industrial waste have created conditions that are extremely destructive to flora and fauna. During the tidal activity pollutants from the northern side moves towards the southern side making the fresh water system also threatened. In addition agricultural inputs from the lands located around the lake also pollute the freshwater region of the lake.

\section{Sampling Stations}

Six sampling stations were selected in the wetland system starting from the northern industrial region to the southern fresh water region. Six surface sediment samples were collected from each site, using a gravity corer with PVC core-liner. Four centimeters of the surface 
sediments were extracted from the core-liner and placed in labeled polythene bags. In the laboratory the sediments were air-dried [23] to a constant weight and homogenized with a pestle and mortar, in order to normalize for variation in grain size distribution. The sampling sites are marked in the area map (Figure 1).

\section{Analytical Methods}

For the digestion of the sediment sample one gram of dried and homogenized sediment sample was weighed into $250 \mathrm{ml}$ beaker. An empty beaker was included in the analysis as a reagent empty blank. $50 \mathrm{ml}$ of distilled water was added to the sample. The digestion was performed with a mixture $\mathrm{HNO}_{3}$ and $\mathrm{HClO}_{4}$. Digestion was continued until the volume was reduced to about $15 \mathrm{ml}$. The beakers were allowed to cool to room temperature. The digests were then filtered into a $50 \mathrm{ml}$ volumetric flask and made up to the volume with distilled water [35]. The digested samples were analyzed for heavy metal following Atomic Absorption Spectrophotometer [15] by Thermo M5 series. The concentration of manganese, cadmium, copper, lead, nickel, zinc and mercury were determined in sediment samples and the values are reported in units of $\mathrm{mg} / \mathrm{Kg}$.

The contamination factor for the sediment samples were calculated by the equation;

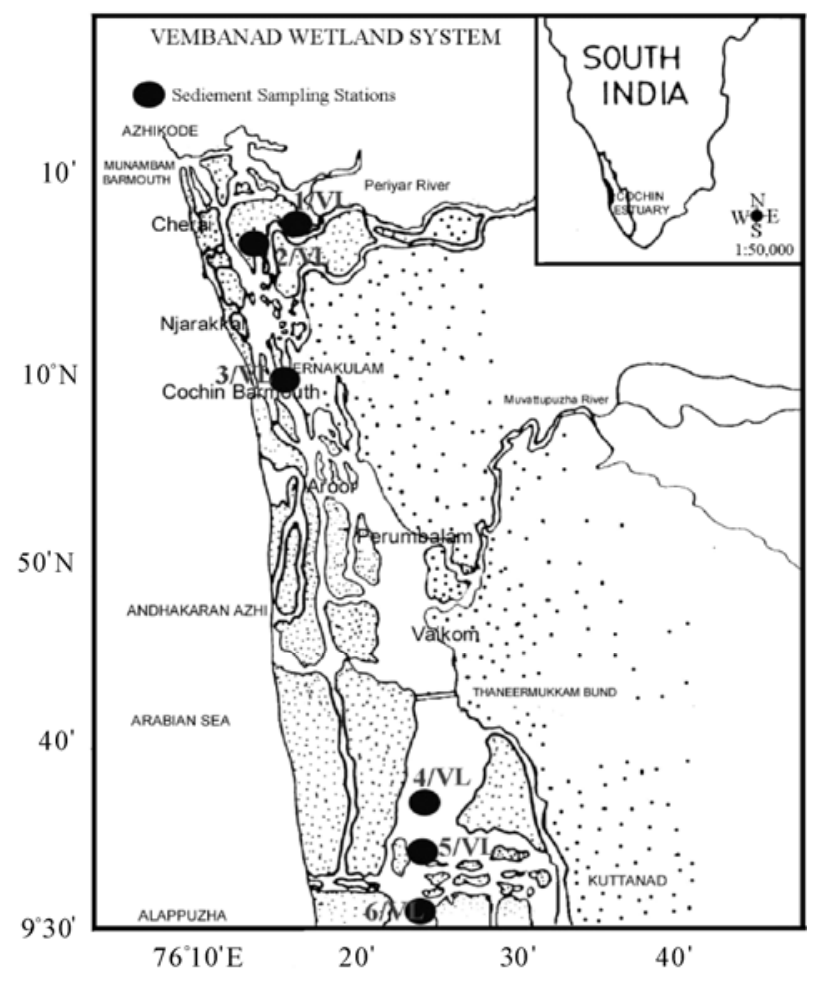

Figure 1. Area map of Vembanad wetland system showing the sediment sampling sites.
Contamination Factor $(\mathrm{CF})=$ Metal content in sediment/Background level of metal

The method proposed by Tomlinson et al. [14] had employed in the present study to find the sediment pollution load index (PLI) which is given by the equation;

$$
\mathrm{PLI}=(\text { Product of } \mathrm{n} \text { number of CF values })^{1 / \mathrm{n}}
$$

Enrichment factors (EF) for metal concentration in sediments at all the stations was calculated and used for comparison. The following equation was used to calculate the EFc values.

$$
\mathrm{EFc}=\mathrm{X} / \mathrm{Fe} \text { (sediment) } / \mathrm{X} / \mathrm{Fe} \text { (Earth's crust) }
$$

where $\mathrm{X}$ is the metal studied and $\mathrm{X} / \mathrm{Fe}$ is the ratio of the concentration of element $\mathrm{X}$ to iron. Iron was chosen as the element of normalization because natural sources (98\%) vastly dominate its input. The crustal abundance data of Bowen [36] were used for all EF values.

The geoaccumulation index Igeo values were calculated for different metals as introduced by Muller [37] is as follows:

$$
\text { Igeo }=\log _{2}\left(C_{n} / 1.5 * B_{n}\right)
$$

where $C_{n}$ is the measured concentration of element $n$ in the sediment simple and $B_{n}$ is the geochemical background for the element $\mathrm{n}$ which is Esther directly measured in pre civilization sediments of the area or taken from the literature (average shale values). The factor 1.5 was introduced to include the possible variation of the background values that are due to lithological variations.

\section{Results}

One of the simple ways of assessing the level of pollution in an aquatic ecosystem is the comparison with different sediment quality guidelines. The range and the mean concentration of heavy metals determined in the sediment samples and their comparative assessment with different international sediment quality guidelines are tabulated in Table 1. The concentration of copper varied from $38.7 \mathrm{mg} / \mathrm{Kg}$ to $1723.75 \mathrm{mg} / \mathrm{Kg}$. Zinc has a variation from $70.7 \mathrm{mg} / \mathrm{Kg}$ to $1963.67 \mathrm{mg} / \mathrm{Kg}$. Manganese concentration in the surface sediments according to the present investigation varied from $320.51 \mathrm{mg} / \mathrm{Kg}$ to 15586.88 $\mathrm{mg} / \mathrm{Kg}$. Cadmium in the sediment ranges from 0.27 $\mathrm{mg} / \mathrm{Kg}$ to $6.35 \mathrm{mg} / \mathrm{Kg}$. The concentration of lead ranged from $21.70 \mathrm{mg} / \mathrm{Kg}$ to $162.59 \mathrm{mg} / \mathrm{Kg}$. Nickel has a variation from $49.59 \mathrm{mg} / \mathrm{Kg}$ to $75.70 \mathrm{mg} / \mathrm{Kg}$.

The level of contamination in aquatic system can be assessed by determining a factor called the degree of contamination $(\mathrm{mCd})$. Elemental background concentration reported for continental crust was used as the reference value. The calculated value for the degree of contamination ranges from 1.47 to 35.39 . The extend of pollution in an aquatic environment can be evaluated by a 
Table 1. Concentration range of different heavy metals and its comparison with different SQGs.

\begin{tabular}{|c|c|c|c|c|c|c|c|c|c|c|c|c|c|c|}
\hline \multirow{2}{*}{$\begin{array}{l}\text { Element } \\
\mathrm{mg} / \mathrm{Kg}\end{array}$} & \multirow{2}{*}{ Mean } & \multirow{2}{*}{ Range } & \multicolumn{2}{|c|}{ Ontario MOE } & \multicolumn{2}{|c|}{ NOAA SQG } & \multicolumn{2}{|c|}{ FDEP SQG } & \multicolumn{2}{|c|}{ CCME } & \multirow{2}{*}{ CSCR } & \multicolumn{3}{|c|}{ USEPA } \\
\hline & & & Low & Severe & ERL & ERM & TEL & PEL & IGM & PEL & & $\begin{array}{c}\text { SQG } \\
\text { NP }\end{array}$ & $\begin{array}{c}\text { SQG } \\
\text { MP }\end{array}$ & $\begin{array}{c}\text { SQG } \\
\text { HP }\end{array}$ \\
\hline $\mathrm{Cu}$ & 799.15 & $38.87-1723.75$ & 16 & 110 & 34 & 270 & 18.7 & 110 & 35.7 & 197 & $60-125$ & $<25$ & $25-50$ & $>50$ \\
\hline $\mathrm{Zn}$ & 528.21 & $70.07-1963.67$ & 120 & 820 & 150 & 410 & 124.0 & 270 & & & $70-400$ & $<90$ & $90-200$ & $>200$ \\
\hline $\mathrm{Mn}$ & 4928.9 & $320.51-15586.88$ & 460 & 1110 & & & & & & & $1500-3000$ & - & - & - \\
\hline $\mathrm{Cd}$ & 6.63 & $0.27-26.35$ & 0.6 & 10 & 1.2 & 9.6 & 0.68 & 4.20 & 0.6 & 3.5 & $3-8$ & - & - & - \\
\hline $\mathrm{Pb}$ & 66.40 & $21.70-162.59$ & 31 & 250 & 46.7 & 218 & 30.2 & 110 & 35 & 91.3 & $100-400$ & $<40$ & $40-60$ & $>60$ \\
\hline $\mathrm{Ni}$ & 64.35 & $49.59-75.70$ & 16 & 75 & 20.9 & 51.6 & 15.9 & 43 & 123 & 315 & 100 & $<20$ & $20-50$ & $>50$ \\
\hline
\end{tabular}

ERL-Effect Range Low, ERM- Effect Range Median, TEL-Threshold Effect Level, PEL-Probable Effect Level, IGM-Interim sediment quality Goals, NP-Non Polluted, MP-Moderately Polluted, HM-Heavily Polluted.

simple method based on pollution load index (PLI). The world average concentration of elements reported for Shale was taken as the reference for PLI. Station 6/VL reported lower PLI value (1.02) and the highest (12.92) was reported for station $2 / \mathrm{VL}$. The potential acute toxicity of contaminants in sediment samples can be estimated as the sum of toxic units $\left(\sum \mathrm{TU}\right)$ defined as the ratio of determined concentration to PEL values. The TU values also show the same trend as like $\mathrm{mCd}$ and PLI. The different values observed for degree of contamination, pollution load index and sum of toxic units are summarized in Table 2. All the values indicated metal contamination in the Vembanad Lake.

A common approach to estimate how much the sediment is impacted (naturally and anthropogenically) with heavy metal is to calculate the enrichment factor $(\mathrm{EF})$ for metal concentrations above uncontaminated background levels. The average standard reported for Shale was used as the reference value in the present study. The enrichment factors for different metals in different stations are tabulated in Table 3. Index of geochemical accumulation (Igeo) has been used widely to evaluate the degree of metal contamination or pollution in terrestrial, aquatic and marine environment. World average reported for Shale was used as the control in the present study. Geoaccumulation index for different stations is summarized in Table 4.

Correlation matrix provides clues about the carrier substances and the chemical association of these metals in the ecosystem. In the present study Pearson's correlation has employed for different metals with organic matter. The correlation matrix is given in Table 5.

\section{Discussion}

\subsection{Spatial Variation of Heavy Metals}

Figure 2 represents the spatial variation of different heavy metals in the surface sediments of Vembanad wetland system. The mean concentration of different heavy metals follows the order manganese $>$ copper $>$ zinc $>$ lead $>$ nickel $>$ cadmium $>$ mercury. The average concentration of copper is $799.15 \mathrm{mg} / \mathrm{Kg}$, which was above the all compared sediment quality guidelines. The highest deposition was found in the Cochin bar mouth and lowest was reported in the station $6 / \mathrm{VL}$, which is in the southern end. High level of copper indicates a higher input of organic matter deposition, which might be from urban and industrial waste water sediment deposition. The average concentration of zinc is $528.21 \mathrm{mg} / \mathrm{Kg}$, which was also above the all sediment quality guidelines. Manganese in earth crust is $1060 \mathrm{mg} / \mathrm{Kg}$; in soils it is 61 $1060 \mathrm{mg} / \mathrm{Kg}$. The station 2/VL has reported 15586.88 which is far away from the guideline values. A uniform decreasing trend was observed for manganese except for the station $1 / \mathrm{VL}$. The average abundance of cadmium in the earth crust is $0.16 \mathrm{ppm}$; in soils it is $0.1-0.5 \mathrm{mg} / \mathrm{Kg}$. Increased cadmium concentration might be related to industrial activity, atmospheric emission and deposition of organic and fine grain sediments. Lead is considered as a good indicator of pollution by urban run-off water. The use of gasoline is mainly responsible for the lead pollution especially in urban area. The average concentration of lead in the present study is $66.40 \mathrm{mg} / \mathrm{Kg}$, which is in the category of highly polluted sediments according to United State Environmental Protection Agency Guidelines. The background value of nickel in the earth crust is $1.2 \mathrm{mg} / \mathrm{Kg}$; in soil it is $2.5 \mathrm{mg} / \mathrm{Kg}$. Nickel is used principally in its metallic form combined with other metals and nonmetals as alloys. The mean value of nickel is 64.35 $\mathrm{mg} / \mathrm{Kg}$, which is above the United State Environmental Protection Agency Guidelines for highly polluted sediments. The mercury pollution is severe in the sediments of the Cochin bar mouth with a concentration of 4.91 $\mathrm{mg} / \mathrm{Kg}$. 
Table 2. Spatial variation of heavy metals and different index values.

\begin{tabular}{|c|c|c|c|c|c|c|c|c|}
\hline Element/Stations & $1 / \mathrm{VL}$ & $2 / \mathrm{VL}$ & $3 / \mathrm{VL}$ & $4 / \mathrm{VL}$ & $5 / \mathrm{VL}$ & 6/VL & Continental Crust & Average shale \\
\hline $\mathrm{Cu} \mathrm{mg} / \mathrm{Kg}$ & 1346.25 & 1588.13 & 1723.75 & 47.60 & 50.30 & 38.87 & 55.00 & 45.00 \\
\hline $\mathrm{Zn} \mathrm{mg/Kg}$ & 578.11 & 1963.67 & 70.07 & 223.00 & 156.68 & 177.75 & 70.00 & 95.00 \\
\hline $\mathrm{Mn} \mathrm{mg} / \mathrm{Kg}$ & 4040.00 & 15586.88 & 8714.38 & 501.67 & 320.51 & 410.00 & 950.00 & 900.00 \\
\hline $\mathrm{Cd} \mathrm{mg/Kg}$ & 7.03 & 26.35 & 5.23 & 0.27 & 0.35 & 0.55 & 0.20 & 0.30 \\
\hline $\mathrm{Pb} \mathrm{mg} / \mathrm{Kg}$ & 27.18 & 78.27 & 162.59 & 28.65 & 80.03 & 21.70 & 12.50 & 20.00 \\
\hline $\mathrm{Ni} \mathrm{mg} / \mathrm{Kg}$ & 70.56 & 72.82 & 49.59 & 64.73 & 75.70 & 52.67 & 75.00 & 68.00 \\
\hline $\mathrm{Hg}, \mathrm{mg} / \mathrm{Kg}$ & 0.56 & 0.23 & 4.91 & 0.136 & 0.345 & 0.270 & & \\
\hline mCd & 12.54 & 35.39 & 13.55 & 1.51 & 2.11 & 1.47 & & \\
\hline PLI & 5.48 & 12.92 & 5.52 & 1.09 & 1.23 & 1.02 & & \\
\hline SUM TU & 17.94 & 30.39 & 19.81 & 3.09 & 3.61 & 2.56 & & \\
\hline
\end{tabular}

mCd: Degree of Contamination, PLI- Pollution Load Index, SUM TU- Sum of Toxic Units.

Table 3. Enrichment factor calculated for the sediment samples of Vembanad wetland system.

\begin{tabular}{|c|c|c|c|c|c|c|}
\hline \multirow{2}{*}{ Element/Stations } & \multicolumn{6}{|c|}{ Enrichment Factor } \\
\hline & $1 / \mathrm{VL}$ & $2 / \mathrm{VL}$ & $3 / \mathrm{VL}$ & $4 / \mathrm{VL}$ & $5 / \mathrm{VL}$ & $6 / \mathrm{VL}$ \\
\hline $\mathrm{Cu}$ & 19.94 & 23.53 & 25.54 & 0.71 & 0.75 & 0.58 \\
\hline $\mathrm{Zn}$ & 4.06 & 13.78 & 0.49 & 1.56 & 1.10 & 1.25 \\
\hline $\mathrm{Mn}$ & 2.99 & 11.55 & 6.46 & 0.37 & 0.24 & 0.30 \\
\hline $\mathrm{Cd}$ & 15.61 & 58.56 & 11.61 & 0.59 & 0.79 & 1.21 \\
\hline $\mathrm{Pb}$ & 0.91 & 2.61 & 5.42 & 0.95 & 2.67 & 0.72 \\
\hline $\mathrm{Ni}$ & 0.63 & 0.71 & 0.49 & 0.63 & 0.74 & 0.52 \\
\hline
\end{tabular}

Table 4. Sediment geo-accumulation index (Igeo) calculated for sediments of Vembanad wetland system.

\begin{tabular}{|c|c|c|c|c|c|c|}
\hline \multirow{2}{*}{ Element/Stations } & \multicolumn{6}{|c|}{ Index of Geo-accumulation } \\
\hline & $1 / \mathrm{VL}$ & $2 / \mathrm{VL}$ & $3 / \mathrm{VL}$ & $4 / \mathrm{VL}$ & $5 / \mathrm{VL}$ & $6 / \mathrm{VL}$ \\
\hline $\mathrm{Cu}$ & 4.32 & 4.56 & 4.67 & -0.50 & -0.42 & -0.80 \\
\hline $\mathrm{Zn}$ & 2.02 & 3.78 & -1.02 & 0.65 & 0.14 & 0.32 \\
\hline $\mathrm{Mn}$ & 1.58 & 3.53 & 2.69 & -1.43 & -2.07 & -1.72 \\
\hline $\mathrm{Cd}$ & 3.96 & 5.87 & 3.54 & -0.75 & -0.35 & 0.28 \\
\hline $\mathrm{Pb}$ & -0.14 & 1.38 & 2.44 & -0.07 & 1.42 & -0.47 \\
\hline $\mathrm{Ni}$ & -0.67 & -0.49 & -1.04 & -0.66 & -0.43 & -0.95 \\
\hline
\end{tabular}


Table 5. Pearson Correlation Matrix for different heavy metals with organic matter.

\begin{tabular}{|c|c|c|c|c|c|c|c|c|}
\hline & $\mathrm{Cu}$ & $\mathrm{Zn}$ & $\mathrm{Mn}$ & $\mathrm{Cd}$ & $\mathrm{Pb}$ & $\mathrm{Ni}$ & $\mathrm{Hg}$ & O.M \\
\hline $\mathrm{Cu}$ & 1.00 & 0.50 & 0.84 & 0.68 & 0.57 & -0.08 & 0.57 & -0.27 \\
\hline $\mathrm{Zn}$ & & 1.00 & 0.81 & 0.97 & -0.04 & 0.48 & -0.32 & 0.53 \\
\hline $\mathrm{Mn}$ & & & 1 & 0.93 & 0.50 & 0.08 & 0.29 & 0.11 \\
\hline $\mathrm{Cd}$ & & & & 1.00 & 0.19 & 0.34 & -0.07 & 0.37 \\
\hline $\mathrm{Pb}$ & & & & & 1.00 & -0.31 & 0.87 & -0.31 \\
\hline $\mathrm{Ni}$ & & & & & & 1.00 & -0.65 & 0.86 \\
\hline $\mathrm{Hg}$ & & & & & & & 1.00 & -0.70 \\
\hline O.M & & & & & & & & 1.00 \\
\hline
\end{tabular}

O.M: Organic Matter.
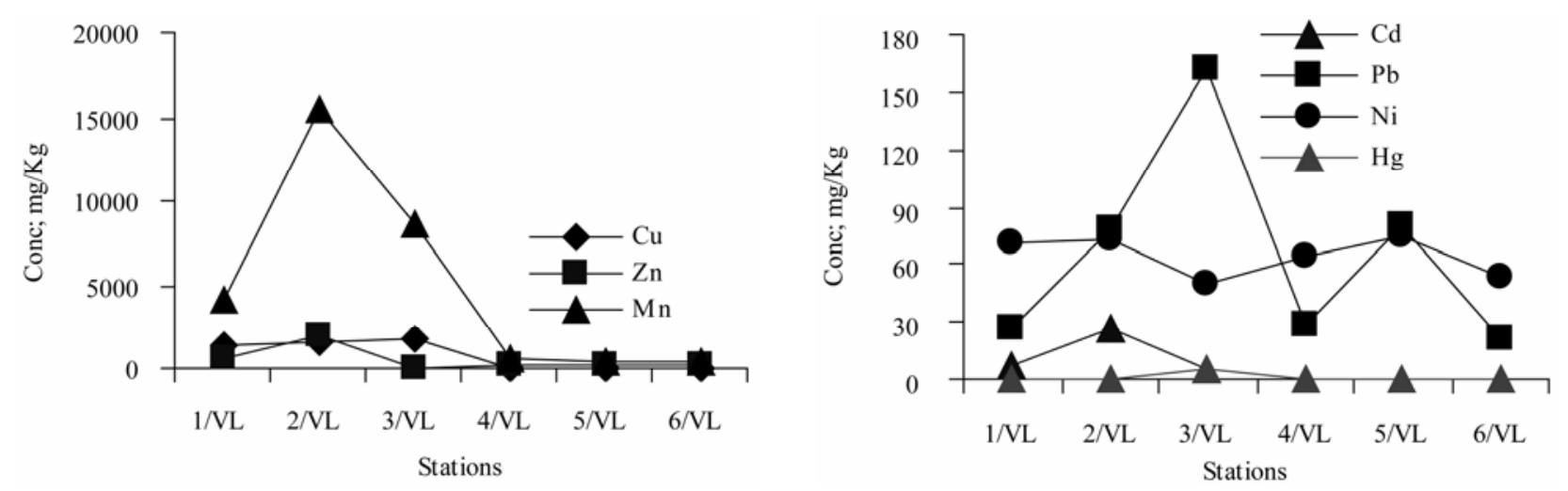

Figure 2. Spatial variation of different heavy metals in the surface sediments.

\subsection{Sediment Quality Indices}

The index value of various sediment quality indices such as degree of contamination, pollution load index and sum of toxic units are depicted in Figure 3. The degree of contamination $(\mathrm{mCd})$ in an ecosystem is usually expressed by the following terminologies.

$\mathrm{mCd} \leq 1.5$ nil to very low degree of contamination

$1.5 \leq \mathrm{mCd}<2$ low degree of contamination

$2 \leq \mathrm{mCd}<4$ moderate degree of contamination

$4 \leq \mathrm{mCd}<8$ high degree of contamination

$8 \leq \mathrm{mCd}<16$ very high degree of contamination

$16 \leq \mathrm{mCd}<32$ extremely high degree of contamination $\mathrm{mCd} \geq 32$ ultra high degree of contamination

Comparison of the results with the above terminologies indicated that ultra degree of contamination is observed at the station $2 / \mathrm{VL}$ which is located near the outlets of many industries. The other two stations $1 / \mathrm{VL}$ and $2 / \mathrm{VL}$, near by the industrial units indicated very high degree of contamination. Moving towards the south a comparative decrease in the contamination was observed.
The two stations, 4/VL and 5/VL experienced low degree of contamination. Sediment in the southern end indicated very low degree of contamination. The spatial variation of degree of contamination indicated that the movement of contaminated water and sediments from estuarine region to southern half of Vembanad wetland system at the time of high tide contaminated the fresh water region to some extend.

The pollution load index of the wetland follows the same order as the degree of contamination. If the PLI value is greater than one it indicates pollution and if it is less than one it shows no pollution. The PLI can provide information about the quality of the environment, which provides valuable information to the decision makers on the pollution level of the area. Hence according to PLI values all the stations in the wetland system is polluted.

The sediment quality guidelines of the National Oceanographic and Atmospheric Administration (NOAA) of the Unite States shows Effect Range Low (ERL) and Effect Range Median (ERM) values, which represents the percentile ranges of toxicity tolerance in bioassay 


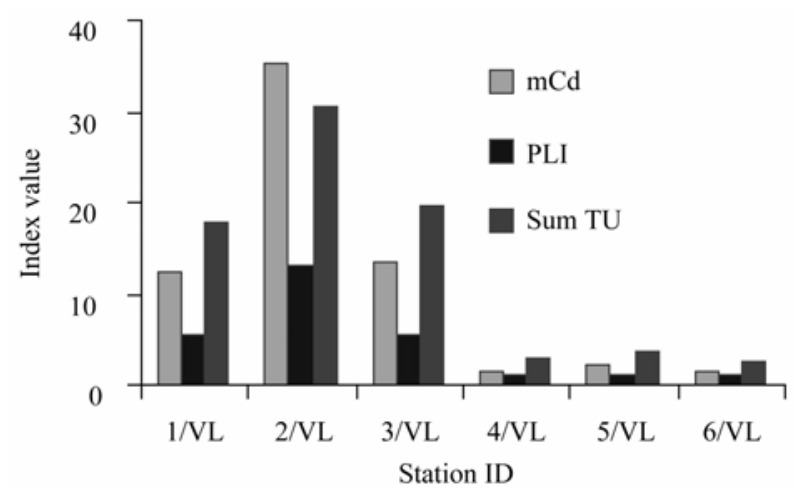

Figure 3. Variation of different sediment quality index values for Vembanad wetland system.

tests for aquatic and benthic biota. These effects are given by

Metal $<$ ERL minimal effect range biological effects are rarely observed

ERL $<$ Metal $<$ ERM moderate effect range biological effects occur occasionally

Metal > ERM probable effect range biological effects occur frequently

The mean concentration of copper and zinc exceeded the ERM limits, which represents a probable effect range with in which adverse biological effects frequently occur. Spatial variation of trace elements indicated that biological effects are rare in southern half and frequent in estuarine side. The potential acute toxicity for the sediments were determined by calculating the sum of toxic units and showed similar trend like $\mathrm{mCd}$ and PLI.

The enrichment factor method normalizes the measured heavy metal content with respect to a sample reference such as iron. It can be used to differentiate between the metal originating from anthropogenic activities and those from natural procedure, and to assess the degree of anthropogenic influence. Five contamination categories are recognized on the basis of the enrichment factor, which are

\section{$\mathrm{EF}<2$ deficiency to minimal enrichment}

EF 2 - 5 moderate enrichment

EF 5 - 20 significant enrichment

EF 20 - 40 very high enrichment

EF $>40$ extremely high enrichment

A value of $0.5 \leq \mathrm{EF} \leq 1.5$ suggests that traces of metal may be due to crystal materials or natural weathering processes. Samples having EF value greater than 5 are considered to be contaminated with that particular element. Figure 4 represents all the EF values of the heavy metals. The station $2 / \mathrm{VL}$ showed very high enrichment for the metal cadmium. It is presumed that high EF values indicate an anthropogenic source of heavy metals, mainly from activities such as industrialization and ur- banization. Comparatively less enrichment was observed in samples of southern region. But according to Khan et al. [38] EF value less than one are considered significant. Areas with EF values $<1$ should be viewed with caution as they imply preferential release of these metals, making them bioavailabe.

The Index of geo-accumulation calculated for the degree of metal pollution is assessed in terms of seven contamination classes based on the increasing numerical value of the index as follows:

\section{Igeo}

Igeo $<0$ unpolluted

$0<=$ Igeo $<1$ unpolluted to moderately polluted

$1<=$ Igeo $<2$ moderately polluted

$2<=$ Igeo $<3$ moderately polluted to strongly polluted

$3<=$ Igeo $<4$ strongly polluted

$4<=$ Igeo $<5$ strongly polluted to very strongly polluted

Igeo $>=5$ very strongly polluted

Figure 5 represents the geo-accumulation index for different heavy metals in the wetland. It indicates strong pollution in the industrial zone and unpolluted to moderate pollution in the freshwater region. Elements copper

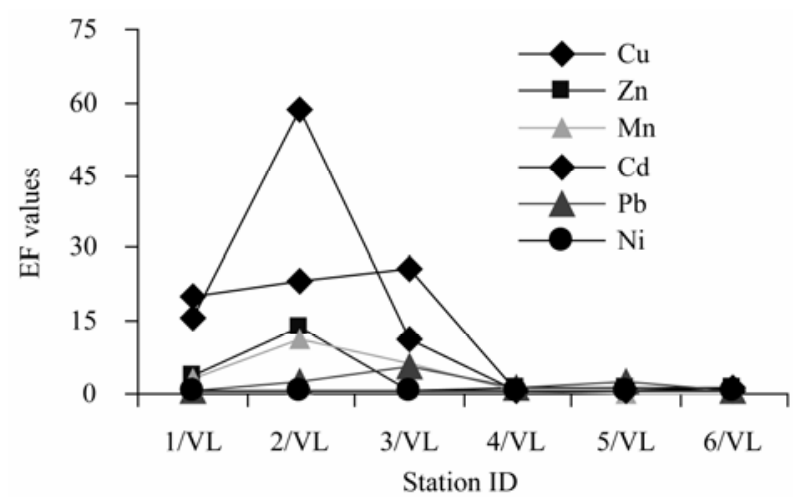

Figure 4. Variation of enrichment factor along different stations.

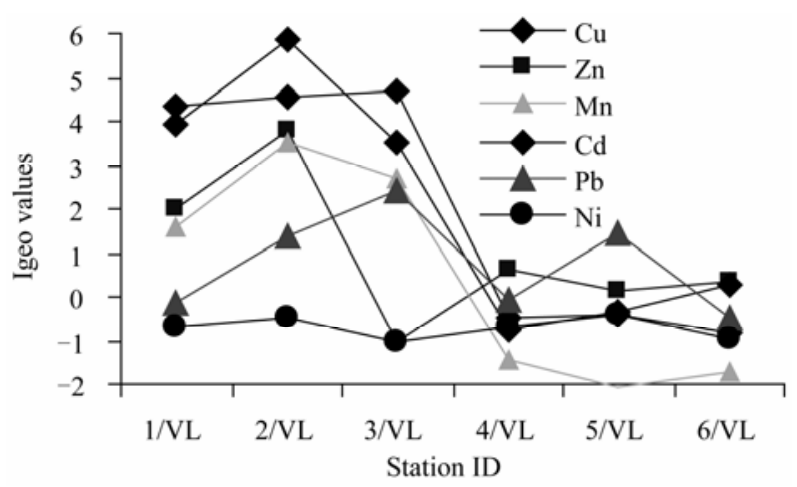

Figure 5. Variation of geo-accumulation index for different stations. 
and cadmium have higher values in northern half where as it is very low in southern side.

\subsection{Pearson's Correlation Matrix}

Correlation analysis of heavy metals with organic matter present in the sediment was carried out. Zinc and nickel have good correlation with organic matter where as mercury have a strong negative correlation. The element cadmium has good correlation with all other elements except mercury. Copper also has good correlation with other metals except nickel and organic matter. The percentage of different metals in the sediments of fresh water region with reference to industrial zone was calculated. The concentration of nickel in both the regions was same, which indicated the higher mobility of the metal nickel. The lowest percentage was reported for copper, which indicated its lower mobility. The above facts were conformed from the correlation matrix, where nickel has good correlation with organic matter and copper have no correlation. Hence the concentration of the heavy metals in fresh water is a proportionate of the mobility of metal and contamination load at industrial side.

\section{Conclusions}

The study of "Ecotoxicity and ecosystem health of a Ramsar wetland system of India" showed a clear pattern of anthropogenic impact on Vembanad wetland system. From the observation it is clear that manganese and copper showed more pronounced level followed by zinc, lead, nickel, cadmium and mercury. Comparison of heavy metal concentration with different international sediment quality guidelines indicated that most of the heavy metal concentration in the northern side of the wetland system has crossed the extreme limits where as southern half is with in the range of guideline values. The assessment of level of contamination by calculating the degree of contamination for different stations confirmed ultra degree of contamination at station near by industrial area. Enrichment factor determined for the deferent heavy metals indicated anthropogenic origin of heavy metal in estuarine side. Index of geo-accumulation was also showed the same trend like enrichment factor. According to NOAA guidelines the health of the ecosystem was seriously impaired with frequent biological effects were occurring in estuarine side. The extend of pollution at the fresh water region also depends on the mobility of the specific metal. Nickel has higher mobility which has hundred percentage contribution, where as copper is less mobile which indicated its lowest contribution from the industrial zone. Anthropogenic source from the industrial activities at the upstream of the wetland contributed huge load of heavy metals to the estuarine region which is seriously attacking the fresh water region of the Vembanad wetland system.

\section{Acknowledgements}

The authors wish to express their gratitude to the Department of Science and Technology (DST), Government of India for the financial assistance to carryout the research work.

\section{REFERENCES}

[1] A. S. Cohen, "Paliolimnology," Oxford University Press, New York, 2003.

[2] Fagbote Emmanuel Olubunmi and Olanipekun Edward Olorunsola, "Evaluation of the Status of Heavy Metal Pollution of Sediment of Agbabu Bitumen Deposit Area, Nigeria," European Journal of Scientific Research, Vol. 41, No. 3, 2010, pp. 373-382.

[3] O. K. Adeyemo, O. A. Adedokun, R. K. Yusuf and E. A. Adeleye, "Seasonal Changes in Physicao-Chemical Parameters and Nutrient Load of River Sediment in Ibadan City, Nigeria," Global NEST Journal, Vol. 10, No. 3, 2008, pp. 326-336.

[4] O. A. Davies and J. F. N. Abowei, "Sediment Quality of Lower Reaches of Okpoka Creek, Niger Delta, Nigeria," European Journal of Scientific Research, Vol. 26, No. 3, 2009, pp. 437-442.

[5] S. M. Praveena, M. Radojevic, M. H. Abdullah and A. Z. Avis, "Factor-Cluster Analysis and Enrichment Study of Mangrove Sediments-An Example from Mengkabong Sabah," The Malaysian Journal of Analytical Sciences, Vol. 2, No. 2, 2007, pp. 421-430.

[6] A. Akinmosin, O. O. Osinowo and M. A. Oladunjoye, "Radiogenic Components of the Nigeria Tarsand Deposits," Earth Science Research Journal, Vol. 13, No. 1, 2009, pp. 64-73.

[7] S. O. Ajayi and O. Osibanjo, "Pollution Studies in Nigerian Rivers. Water Quality of Some Nigerian River," Environment Pollution (Series B), Vol. 2, 1981, pp. 87-95. doi:10.1016/0143-148X(81)90044-6

[8] M. Chen and Q. Mal, "Comparison of Three Aqua Regia Digestion Methods for Twenty Florida Soils," Soil Science Society of America Journal, Vol. 65, No. 2, 2001, pp. 491-499. doi:10.2136/sssaj2001.652491x

[9] V. Sandroni, M. M. C. Smith and A. Donovan, "Microwave Digestion of Sediment, Soils and Urban Particulate Matter for Trace Metal Analysis," Talanta, Vol. 60, No. 4, 2003, pp. 715-719. doi:10.1016/S0039-9140(03)00131-0

[10] S. Mc Cready, G. F. Birch and S. E. Taylor, "Extraction of Heavy Metals in Sydney Harbour Sediments Using 1M $\mathrm{Hcl}$ and $0.05 \mathrm{M}$ EDTA and Implications for Sediment Quality Guidelines," Australian Journal of Earth Sciences, Vol. 50, No. 2, 2003, pp. 249-255. doi:10.1046/j.1440-0952.2003.00994.x

[11] A. Jones-Lee and G. F. Lee, "Unreliability of Co-occur- 
Rence Based Sediment Quality Guidelines for Contaminated Sediment Evaluation at Superfund/Hazardous Chemical Sites," Journal of Remediation, Vol. 15, No. 2, 2005, pp. 19-33. doi:10.1002/rem.20040

[12] G. Perin, M. Bonardi, R. Fabris, B. Simoncini, S. Manente, L. Tosi and S. Scotto, "Heavy Metal Pollution in Central Venice Lagoon Bottom Sediments: Evaluation of the Metal Bioavailability by Geochemical Speciation Procedure," Environmental Technology, Vol. 18, No. 6, 1997, pp. 593-604. doi:10.1080/09593331808616577

[13] L. Hakanson, "Ecological Risk Index for Aquatic Pollution Control. A Sedimentological Approach," Water ReSearch, Vol. 14, 1980, pp. 975-1001. doi:10.1016/0043-1354(80)90143-8

[14] D. C. Tomlinson, J. G. Wilson, C. R. Harris and D. W. Jeffery, "Problems in the Assessment of Heavy Metals Levels in Estuaries and the Formation of a Pollution Index," Helgol Wiss Meeresunters, Vol. 33, No. 1-4, 1980, pp. 566-575. doi:10.1007/BF02414780

[15] USEPA, "Sediment Classification Method Compendium," EPA, Washington DC, 1992.

[16] E. R. Long, D. D. Macdonald, S. L. Smith and F. D. Calder, "Incidence of Adverse Biological Effects with in Ranges of Chemical Concentrations in Marine and Estuarine Sediments," Environmental Management, Vol. 19, No. 1, 1995, pp. 81-97. doi:10.1007/BF02472006

[17] E. R. Long and D. D. Macdonald, "Recommended Use of Empirically Derived Sediment Quality Guidelines for Marine and Estuarine Ecosystems," Humman and Ecological Risk Assessment, Vol. 4, No. 5, 1998, pp. 10191039. doi:10.1080/10807039891284956

[18] D. D. McDonald, C. G. Ingersoll and T. A. Berger, "Development and Evaluation of Consensus-Based Sediment Quality Guidelines for Freshwater Ecosystems," Archives of Environmental Contamination and Toxicology, Vol. 39, No. 1, 2000, pp. 20-31. doi:10.1007/s002440010075

[19] G. Bakan and H. B. Ozkoc, "An Ecological Risk Assessment of the Impact of Heavy Metals in Surface Sediments on Biota from the Mid-Black Sea Coast of Turkey," International Journal of Environmental Studies, Vol. 64, No. 1, 2007, pp. 45-57.

[20] F. Pederson, E. Bjorestad, H. V. Anderson, J. Kjolholt and C. Poll, "Characterization of Sediments from Copenhagen Harbour by Use of Biotests," Water Science and Technology, Vol. 37, No. 6-7, 1998, pp. 233-240. doi:10.1016/S0273-1223(98)00203-0

[21] G. M. S. Abrahim and P. J. Parker, "Assessment of Heavy Metal Enrichment Factors and the Degree of Contamination in Marine Sediment from Tamaki Estuary, Auckland, New Zealand," Environmental Monitoring and Assessment, Vol. 136, 2008, pp. 227-238. doi:10.1007/s10661-007-9678-2

[22] L. L. Mediolla, M. C. D. Domínguez and M. R. G. Sandoval, "Environmental Assessment of and Active Tailings Pile in the State of Mexico (Central Mexico)," Research Journal of Environmental Sciences, Vol. 2, No. 3, 2008, pp. 197-208. doi:10.3923/rjes.2008.197.208
[23] A. S. Jumbe and N. Nandini, "Heavy Metals Analysis and Sediment Quality Values in Urban Lakes," American Journal of Environmental Sciences, Vol. 5, No. 6, 2009, pp. 678-687. doi:10.3844/ajessp.2009.678.687

[24] G. Müller, "Schwermetalle in Den Sedimenten des Rheins-Veränderungen Seit 1971," Umschau, Vol. 79, 1979, pp. 778-783.

[25] G. Müller, "Schwermetalle in den sedimenten des Elbe bei Stade," Naturwissenschaften, Vol. 67, 1980, pp. 560561. doi:10.1007/BF00450667

[26] M. Singh, A. A. Ansari, G. Müller and I. B. Singh, "Heavy Metals in Freshly Deposited Sediments of the Gomati River (a Tributary of the Ganga River): Effects of Human Activities," Environmental Geology, Vol. 29, No. 3-4, 1997, pp. 246-252. doi:10.1007/s002540050123

[27] M. Kralik, "A Rapid Procedure for Environmental Sampling and Evaluation of Polluted Sediments," Applied Geochemistry, Vol. 14, No. 6, 1999, pp. 807-816. doi:10.1016/S0883-2927(98)00096-1

[28] P. Stoffers, G. P. Glasby, C. J. Wilson, K. R. Davies and P. Walter, "Heavy Metal Pollution in Wellington Harbor. New Zealand," Journal of Marine Freshwater Research, Vol. 20, 1986, pp. 495-512. doi: $10.1080 / 00288330.1986 .9516169$

[29] G. W. Bryan and W. J. Langston, "Bioavailability, Accumulation and Effects of Heavy Metals in Sediments with Special Reference to United Kingdom Estuaries: A Review," Environmental Pollution, Vol. 76, No. 2, 1992, pp. 89-131. doi:10.1016/0269-7491(92)90099-V

[30] W. W. Dickinson, G. B. Dunbar and H. McLeod, "Heavy Metal History from Cores in Wellington Harbour, New Zealand," Environmental Geology, Vol. 27, No. 1, 1996, pp. 57-69. doi:10.1007/BF00770603

[31] K. K. T. Balachandran, M. Joseph, V. N. Nair, V. K. Sankaranarayanan and P. Sheeba, "Geochemistry of Surficial Sediments along the Central Southwest Coast of India-Seasonal Changes in Regional Distribution," Journal of Coastal Research, Vol. 19, No. 3, 2003, pp. 664683.

[32] P. S. Harikumar, K. Madhavan, P. Shimjidha and K. R. Bindu, "Study on Hydrochemistry and Sediment Quality of Vemband Lake in the Southwest (Kerala) Coast of India," Eco-Chronicle, Vol. 2, No. 2, 2007, pp. 69-80.

[33] P. S. Harikumar and U. P. Nasir, "Ecotoxicological Impact Assessment of Heavy Metals in Core Sediments of a Tropical Estuary," Ecotoxicology and Environmental Safety, Vol. 73, No. 7, 2010, pp. 1742-1747. doi:10.1016/i.ecoenv.2010.08.022

[34] P. S. Harikumar, U. P. Nasir, and M. P. M. Rahman, "Distribution of Heavy Metals in the Core Sediments of a Tropical Wetland System," International Journal of Environmental Science and Technology, Vol. 6, No. 2, 2009, pp. 222-232.

[35] ASTM, "D 3974, Standard Practices for Extraction of Trace Elements from Sediments," ASTM International, 100 Barr Harber Drive, West Conshohocken, 1981, pp. 393-395. 
[36] H. J. M. Bowen, "Environmental Chemistry of the Elements," Academic Press, New York, 1979.

[37] G. Muller, "Index of Geoaccumulation in Sediments of the Rhine River," Geojournal, Vol. 2, No. 3, 1969, pp. 108-118.

[38] A. H. Khan, R. F. Nolting, S. J. V. Gaast and W. Van
Raaphorst, "Trace Element Geochemistry at the Sediment Water Interface in the North Sea and the Western Wadden Sea," Netherlands Institute for Sea Research. NIOZ Report 1992-10, BARC Report 1992-1, BEON Report 18, 1992. 